\title{
Physicochemical properties and microstructure of the pregelatinized tannia flour prepared by a simple parboiling method
}

\author{
I Nengah Kencana Putra*, I Putu Suparthana, Ni Putu Timur Ina \\ Department of Food Science and Technology, Udayana University, Bali, Indonesia
}

\begin{abstract}
Received:
June 15, 2019

Accepted:

January 26, 2020

Published:

April 25, 2020

Abstract

The flour of tannia tuber has the potential to be used as raw material for various flourbased food products. However, some of its functional properties are still limited, so it needs to be improved. This study aimed to determine the effect of parboiling treatment on the physicochemical properties of pregelatinized tannia flour (PTF). PTF preparation was carried out by boiling the tannia tuber slices at varying temperatures and times, before drying in an oven dryer at $70^{\circ} \mathrm{C}$, milling, and sieving through a 60 mesh sieve. The native tannia flour (without parboiling) was also prepared as a control sample. The results showed that the parboiling treatment significantly improved the flour water absorption capacity (WAC) and swelling power (SP), and also it remarkably decreased the flour pasting temperature and pasting time, so it enhanced pasting characteristics of the flour. Parboiling treatment at $95^{\circ} \mathrm{C}$ for 10 minutes generated the fine PTF with WAC $(2.76 \mathrm{~g} / \mathrm{g})$, water soluble index $(6.7 \%)$, SP $(9.08 \mathrm{~g} / \mathrm{g})$, water content $(7.00 \%)$, amylose level (24.68\%), amylopectin level (29.53\%), pasting time (11 minutes), pasting temperature $\left(68.27^{\circ} \mathrm{C}\right)$, final paste viscosity $(1,773.33 \mathrm{cP})$, and type $\mathrm{C}$ pasting profile. Based on its characteristics, PTF is possible to be used as a partial substitute for wheat flour in the production of flour-based foods such as simulated chips, noodles, biscuits, and cakes.
\end{abstract}

Keywords: Tannia pregelatinized flour, Parboiling, Physicochemical properties, Microstructure

\section{How to cite this:}

Putra INK, Suparthana IP and Ina NPT, 2020. Physicochemical properties and microstructure of the pregelatinized tannia flour prepared by a simple parboiling method. Asian J. Agric. Biol. 8(2): 138-146.

*Corresponding author email: nengahkencana@unud.ac.id DOI: https://doi.org/10.35495/ajab.2019.06.257

This is an Open Access article distributed under the terms of the Creative Commons Attribution 3.0 License. (https://creativecommons.org/licenses/by/3.0), which permits unrestricted use, distribution, and reproduction in any medium, provided the original work is properly cited.

\section{Introduction}

Flour is a substance used to make many kinds of food. Wheat flour, for example, is quite popular in Indonesia. To meet the citizen needs, the Indonesian government still imports wheat flour from abroad despite the potentials that exist in this country. Tannia
(Xanthosoma sagittifolium) is an example of an agricultural commodity that can produce flour, and it can be found in many agricultural lands in Indonesia. Tannia has great potential to produce tubers (around 10-25 ton per hectare) (Moorthy et al., 2018). The starch content of tannia tubers can reach $20 \%$ (Moorthy et al., 2018), which can be processed into 
flour. In addition, tannia tubers contain protein $(2.42 \%)$, fat $(0.92 \%)$, carbohydrate $(24.67 \%)$, crude fiber $(3.00 \%)$, vitamin C (90.92 mg/100 g), Zn (0.12 $\mu \mathrm{g} / \mathrm{g}), \mathrm{Ca}(0.31 \mu \mathrm{g} / \mathrm{g})$, and Fe $(0.29 \mu \mathrm{g} / \mathrm{g})$ (Sarma et al., 2016). Some researchers conducted a study of processing bulbs of tannia into flour; for example, Pérez et al. (2007) compared the physicochemical properties of tannia flour and taro flour. Borah and Sit (2015) optimized the drying conditions of tannia tubers in flour production using response surface methodology, and Hoyos-Leyva et al. (2017) characterize the physical and chemical properties of tannia flour. The physical, chemical, and functional characteristics of tannia flour determine the quality of foods made from it. Fine tannia flour which possesses desired properties can be produced through the pregelatinization process which aims to change the physicochemical and functional characteristics of the flour. Pregelatinized tannia flour (PTF) can be an alternative for partly replacing wheat flour in the food production.

Pregelatinized flour can be produced either by the steaming method (Khomsatin et al., 2012) or by the parboiling method (Padmaja et al., 2002; Palupi et al., 2011). The temperature and time of parboiling or steaming are the factors that can affect the characteristics of the product. Khomsatin et al. (2012) suggested that pregelatinized corn flour could be produced by steaming the corn under high pressure $\left(121^{\circ} \mathrm{C}\right.$ or 1,3 bar) for $10-60$ minutes before it was dried and powdered. Meanwhile, Palupi et al. (2011) reported that pregelatinized cassava flour could be produced by boiling cassava tubers at $80^{\circ} \mathrm{C}-100^{\circ} \mathrm{C}$ for 10 minutes before it was dried and powdered. Pregelatinized cassava flour has gelatinization temperature, maximum viscosity, whiteness, water absorption capacity, solubility, and amylose level higher compared to the native one (Hidayat et al., 2009). The amylose level has a linear correlation with water absorption capacity, where the higher the amylose level is, the better can the flour absorb water (Kearsley and Dziedzic, 1995). Furthermore, Padmaja et al. (2002) confirmed that the pregelatinized cassava flour possesses better characteristics compared to the native one.

Although there are many studies on the application of parboiling methods in producing tubers-based pregelatinized flour have been reported (Hidayat et al., 2009; Padmaja et al., 2002), the utilization of this method in the tannia tuber-based pregelatinized flour production is still lacking and is much needed.
Padmaja et al. (2002) suggested that the parboiling method was able to improve the functional properties of cassava flour. Hidayat et al. (2009) reported that water absorption capacity (WAC), solubility, and amylose content of cassava pregelatinized flour is higher than native cassava flour. Studies on sweet potato starch also showed that pregelatinized treatment could increase WAC, solubility, and swelling power (SP) (Marta and Tensiska, 2017). This study aimed to improve the functional properties of tannia flour by the parboiling method. The effect of temperature and time of parboiling on the functional, chemical, and pasting characteristics of PTF were evaluated. This research also used scanning electron microscopy (SEM) to analyze the differences between $\mathrm{PTF}$ and native tannia flour microstructure.

\section{Material and Methods}

\section{Material and instrumentation}

Tannia (Xanthosoma sagittifolium (L.) Schott) tubers with uniform size and the same harvest age were collected directly from farms in Buleleng district, Bali, Indonesia. The tannia tubers were free of mechanical and microbiological damages. All chemicals used were of analytical grade. The main instruments of this research included Spectrophotometer (Genesys 10S UV-Vis, Thermo Fisher Scientific Inc., USA), SEM (JSM-6510, Jeol Ltd., Japan), and Viscometer (DV-II+Pro, Brookfield Engineering Laboratories, Inc. USA).

\section{Experimental design and analysis}

The current study employed a completely randomized design with $3 \times 3$ factorial treatment structure (Steel et al., 1997). The first factor was parboiling temperatures $\left(75^{\circ} \mathrm{C}, 85^{\circ} \mathrm{C}\right.$, and $\left.95^{\circ} \mathrm{C}\right)$, and the second factor was parboiling time (10, 15, and 20 minutes). Data obtained would be analyzed using analysis of variance. If the variation was noticeable among the treatment groups, then the average scores were examined with Duncan's multiple range test DMRT for the differences.

\section{Production of pregelatinized tannia flour (PTF)}

Tannia tubers were washed, peeled manually, and chipped ( $\pm 2 \mathrm{~mm}$ thickness), afterward the slices were immersed into $\mathrm{NaCl} 2 \%$ solution for an hour, cleansed with water, and boiled at temperatures $\left(75^{\circ} \mathrm{C}, 85^{\circ} \mathrm{C}\right.$, and $\left.95^{\circ} \mathrm{C}\right)$ for three different times $(10,15$, and 20 minutes). Next, the tuber slices were drained in oven 
drier at $70^{\circ} \mathrm{C}$. The dried tuber sliced were crushed with a blender and passed through a 60 mesh sieve to obtain PTF.

\section{Determination of WAC}

WAC for each flour sample was determined based on the method suggested by Onuegbu et al. (2013) with slight modifications. Each centrifuge tube was filled with a weighed sample $(2 \mathrm{~g})$ and $9 \mathrm{ml}$ of distilled water, then vortexed for 30 seconds. The suspension was cooled for 30 minutes and centrifuged at 3,000 rpm for 15 minutes. Liquid and sediments inside the centrifuge tube were separated by decantation. The weight of water $(\mathrm{g})$ absorbed by $1 \mathrm{~g}$ of flour was expressed as the WAC.

\section{Determination of water soluble index (WSI) and SP}

WSI and SP for each flour sample were calculated using the method reported by Nathania et al. (2017) with slight modifications. A weighed sample (500 mg) was dissolved into $10 \mathrm{ml}$ of distilled water and heated in a water bath at $60^{\circ} \mathrm{C}$ for 30 minutes with continuous stirring. The suspension was centrifuged at 3,000 rpm for 20 minutes. The supernatant and paste were separated by decantation. The supernatant was oven dried at $105^{\circ} \mathrm{C}$ until it reached a constant weight. WSI of the sample was calculated as a percentage by weight of solids from the sample dry weight. Meanwhile, SP was expressed as the weight (g) of the paste obtained per gram of dry sample.

\section{Starch analysis}

Starch content of the sample was determined using the acid hydrolysis method (Egan et al., 1981). A weighed sample $(2.5 \mathrm{~g})$ was transferred into an Erlenmeyer flask $(50 \mathrm{ml})$, added with distilled water $(50 \mathrm{ml})$, and constantly stirred for 15 minutes. Next, the sample was strained, and the residue was taken and put into another Erlenmeyer flask $(250 \mathrm{ml})$, combined with 5 $\mathrm{ml}$ of $\mathrm{HCl}(4 \mathrm{~N})$ and $100 \mathrm{ml}$ of distilled water, and then heated in a water bath for 2 hours. The mixture was cooled and neutralized by adding three drops of phenolphthalein and $\mathrm{NaOH}(50 \%)$ until it turned to pink. Following, the mixture was diluted with distilled water until it reached the desired volume $(250 \mathrm{ml})$, passed through filter paper, and the filtrate obtained $(0.5 \mathrm{ml})$ was put into an Erlenmeyer flask $(50 \mathrm{ml})$, added Luff Schoorl solution $(10 \mathrm{ml})$ and distilled water $(9.5 \mathrm{ml})$. Furthermore, the mixture was boiled (using reflux) until a red precipitate was formed, then cooled. Subsequently, the mixture was added with 10 $\mathrm{ml}$ of $\mathrm{H}_{2} \mathrm{SO}_{4}(20 \%), 5 \mathrm{ml}$ of $\mathrm{KI}(20 \%)$, and amylum (as an indicator), then titrated with Na-thiosulfate $(0.1$ $\mathrm{N})$. Starch content of the sample was calculated using the following formula.

$$
\text { Starch content }=\frac{0.9 \times K \times F}{\text { sample wight }(\mathrm{mg})} \times 100 \%
$$

$K=$ reducing sugars content based on Luff Schoorl table

$F=$ dilution factor

\section{Amylose and amylopectin analysis}

The amylose content of starch was determined using the colorimetric iodine method (Juliano, 1971) with modifications. A weighed sample ( $1 \mathrm{~g})$ was put into a test tube $(50 \mathrm{ml})$, added with $9 \mathrm{ml}$ of $\mathrm{NaOH}(1 \mathrm{M})$, vortexed, and heated in a boiling water bath for 30 minutes. The solution $(0.25 \mathrm{ml})$ was inserted into a volumetric flask $(10 \mathrm{ml})$, added with $0.5 \mathrm{ml} \mathrm{KI} / \mathrm{Iod}$, $0.5 \mathrm{ml}$ acetic acid solution, and filled with distilled water to the limit. The mixture was shaken up and left for 20 minutes. Its absorbance level was then measured with a UV-Vis spectrophotometer at a particular wavelength $(620 \mathrm{~nm})$. The absorbance value was plotted on a standard curve. The regression equation curve was y $=0.97 \times+2.96$ and the $R$ square value was 0.96 . The amylose content was calculated based on the relationship between the absorbance value of the sample and the amylose concentration on the standard curve. Concurrently, the amylopectin content was determined by calculating the difference between the starch content and the amylose content (Okporie et al., 2014).

\section{Pasting profile observation}

The pasting profile of tannia flour was observed using a Viscometer (DV-II+Pro, Brookfield Engineering Laboratories, Inc. USA) based on a method suggested by AAC (1995). A weighed sample (1 g) was dissolved into $10 \mathrm{ml}$ of distilled water in a heating vessel. A spindle was put into it. It was then rotated at $100 \mathrm{rpm}$. The temperature was raised at an average rate of $3.5^{\circ} \mathrm{C} /$ minutes until it reached $94^{\circ} \mathrm{C}$. This temperature was maintained for 10 minutes and lowered down to $50^{\circ} \mathrm{C}$ at an average rate of $3^{\circ} \mathrm{C} /$ minutes. 


\section{Microstructure observation}

The microstructure of tannia flour was observed using an SEM (JSM-6510, Jeol Ltd., Japan). The sample was coated with gold-palladium, transferred into the microscope, then observed at a potential acceleration of $5 \mathrm{kV}$ and at $750 \times$ magnification.

\section{Results and Discussion}

\section{Physical properties}

The analysis of variance showed that the interaction between parboiling temperature and time was not significant $(p>0.05)$ on the WAC of PTF. Parboiling temperature affected the WAC significantly, whereas parboiling time had no significant impact (Table 1). The WAC would increase when the parboiling temperature was raised. WAC is the ability of flour to absorb water and get swollen. The flour WAC plays a role in determining the consistency and shape of food product created from it (Adepeju et al., 2011; Osundahusi et al., 2003). Findings indicated that WAC of PTF $(2.29-3.04 \mathrm{~g} / \mathrm{g})$ was higher than that of native tannia flour $(1.71 \mathrm{~g} / \mathrm{g})$. It, thus, proved that a parboiling treatment could improve the WAC of flour. Similar results were also reported by Obiegbuna et al. (2014) on cocoyam where the native cocoyam flour had lower WAC $(2.96 \mathrm{~g} / \mathrm{g})$ compared to the pregelatinized cocoyam flour $(3.26 \mathrm{~g} / \mathrm{g})$.

The analysis of variance showed significant interactions between parboiling temperature and time $(p<0.05)$ on WSI and SP. At $75^{\circ} \mathrm{C}$, the heating time significantly affected WSI, while at $85^{\circ} \mathrm{C}$ and $95^{\circ} \mathrm{C}$, it did not. This is thought to be caused by the temperature of $75^{\circ} \mathrm{C}$ is still too low for the gelatinization process so that an increase in heating time significantly affects the change in cellulose matrix in the flour granules. At $75^{\circ} \mathrm{C}$ and $95^{\circ} \mathrm{C}$, heating time significantly affected SP, while at $85^{\circ} \mathrm{C}$, it did not. This phenomenon is not yet fully understood, and further research is needed to explain this. Table 1 shows the WSI of PTF fluctuated from $2.98 \%-8.07 \%$. This result was not much different from the WSI of cassava flour $(3.02 \%)$, purple yam $(8.61 \%)$, and white sweet potato $(9.37 \%)$ as reported by Kusumayanti et al. (2015). This study showed that the WSI of PTF was lower than the WSI of native tannia flour. This phenomenon is likely caused by the presence of the cellulose matrix, which is formed during the parboiling process. The matrix could bind a water-soluble component in the flour so that it decreases the water-soluble portion. Other factors such as raw materials, SP, the interaction between amorphous and crystalline areas in starch granules, and the existence of other compounds might also have an impact on the flour WSI (Kumoro et al., 2012).

Table-1. The effect of parboiling temperature and time on the WAC, WSI, and SP of pregelatinized tannia flour.

\begin{tabular}{|c|c|c|c|c|c|}
\hline \multirow{2}{*}{$\begin{array}{c}\text { Parboiling } \\
\text { time (minutes) }\end{array}$} & \multicolumn{3}{|c|}{ Parboiling temperature $\left({ }^{\circ} \mathrm{C}\right)$} & \multirow{2}{*}{ Mean } & \multirow{2}{*}{$\begin{array}{c}\text { Native } \\
\text { tannia } \\
\text { flour }\end{array}$} \\
\hline & 75 & 85 & 95 & & \\
\hline \multicolumn{6}{|c|}{ WAC $(\mathrm{g} / \mathrm{g})^{(-)}$} \\
\hline 10 & 2.29 & 2.65 & 2.76 & $2.57^{\mathrm{A}}$ & \multirow{3}{*}{1.71} \\
\hline 15 & 2.37 & 2.48 & 2.85 & $2.57^{\mathrm{A}}$ & \\
\hline 20 & 2.23 & 2.65 & 3.04 & $2.64^{\mathrm{A}}$ & \\
\hline Mean & $2.30^{\mathrm{B}}$ & $2.59^{\mathrm{A}}$ & $2.88^{\mathrm{A}}$ & & \\
\hline \multicolumn{6}{|c|}{ WSI $(\%)^{(+)}$} \\
\hline 10 & $\begin{array}{c}8.07^{\mathrm{a}} \\
\mathrm{a}\end{array}$ & $\begin{array}{c}5.08^{\mathrm{a}} \\
\mathrm{a}\end{array}$ & $\begin{array}{c}6.75^{\mathrm{a}} \\
\mathrm{a}\end{array}$ & 6.63 & \multirow{3}{*}{10.63} \\
\hline 15 & $\underset{b}{2.98^{b}}$ & $\begin{array}{c}6.77^{a} \\
a\end{array}$ & $\begin{array}{c}3.71^{\mathrm{a}} \\
\mathrm{a}\end{array}$ & 4.49 & \\
\hline 20 & $\begin{array}{c}3.56^{\mathrm{a}} \\
\mathrm{b}\end{array}$ & $\underset{a}{6.15^{a}}$ & $\underset{a}{4.95^{\mathrm{a}}}$ & 4.89 & \\
\hline Mean & 4.87 & 6.00 & 5.14 & & \\
\hline \multicolumn{6}{|c|}{$\mathrm{SP}(\mathrm{g} / \mathrm{g})^{(+)}$} \\
\hline 10 & $\begin{array}{c}7.48^{\mathrm{a}} \\
\mathrm{b}\end{array}$ & $\begin{array}{c}9.9^{\mathrm{a}} \\
\mathrm{a}\end{array}$ & $\begin{array}{c}9.08^{\mathrm{a}} \\
\mathrm{b}\end{array}$ & 8.82 & \multirow{3}{*}{4.25} \\
\hline 15 & $\begin{array}{c}13.04^{\mathrm{a}} \\
\mathrm{a}\end{array}$ & $\begin{array}{c}8.33^{b} \\
a\end{array}$ & $\begin{array}{c}15.07^{\mathrm{a}} \\
\mathrm{a}\end{array}$ & 12.15 & \\
\hline 20 & $\underset{b}{9.34^{\mathrm{a}}}$ & $\begin{array}{c}8.6^{\mathrm{a}} \\
\mathrm{a}\end{array}$ & $\underset{b}{9.59^{a}}$ & 9.18 & \\
\hline Mean & 9.95 & 8.94 & 11.25 & & \\
\hline
\end{tabular}

${ }^{\mathrm{A}-\mathrm{B}}$ Values in row or column followed by the same letter are not significantly different $(p>0.05)$.

${ }^{\mathrm{a}-\mathrm{c}}$ Letters behind or below the values in the same row or column on the same parameter (WSI or SP) indicate not significantly different $(p>0.05) .{ }^{(+)}$Interaction between parboiling temperature and time is significant. ${ }^{(-)}$Interaction between parboiling temperature and time is not significant.

The statistical analysis also revealed a significant effect $(p<0.05)$ of the interaction between temperature and time on the calculated SP. In this study, the SP of PTF ranges from $7.48-15.07 \mathrm{~g} / \mathrm{g}$ (Table 1) closed to the SP of cassava flour $(13.80 \mathrm{~g} / \mathrm{g})$ and sweet potato flour $(3.40 \mathrm{~g} / \mathrm{g})$ as reported in Kusumayanti et al. (2015). Compared to the SP of native tannia flour $(4.25 \mathrm{~g} / \mathrm{g})$, the SP of PTF was higher. The results indicated that parboiling treatment could improve the SP of the flour. A study conducted by Lai (2001) has also shown parboiling treatment $\left(95^{\circ} \mathrm{C}, 40\right.$ minutes) on rice flour could significantly increase SP from 2.42 to $7.42 \mathrm{~g} / \mathrm{g}$. The increase of SP value is influenced by the level of intermolecular associations in starch granules (Kusumayanti et al., 2015) and amylose and amylopectin composition 
(Chan et al., 2009). SP is also related to WSI. Maulani and Hidayat (2016) suggested in their study on hydroxypropylation and Cross-linked Arrowroot Starch that increasing the starch WSI caused the SP of starch to decrease. Flour with high SP can be used to produce a type of food that has a soft and smooth texture with high elasticity such as yellow alkali noodles and Japanese noodles (Aprianita et al., 2014).

\section{Chemical properties}

The effects of parboiling temperature and time on the chemical properties of PTF are shown in Table 2. The results of the statistical analysis showed that all the PTF chemical properties observed in this study (water, amylose, and amylopectin content) were not affected significantly $(p>0.05)$ by the change in parboiling temperature and time. This result indicates that there is no degradation of raw materials components (protein, fat, and carbohydrates) during the parboiling process. The parboiling process in this study was carried out at a medium heating level $\left(75^{\circ} \mathrm{C}-95^{\circ} \mathrm{C}\right)$ and in a short period (10-20 minutes), so it was thought to not cause significant degradation of raw material components. In this study, the water content of the PTF $(6.35 \%-7.71 \%)$ was slightly higher than of the native tannia flour $(5.96 \%)$. This phenomenon could happen because PTF had a better capacity in holding water compared to the native tannia flour. The water content of PTF calculated in this study was almost similar to that of instant cocoyam flour (6.3\%), and yam flour (5.6\%) as suggested in Oladeji et al. (2013).

The PTF contained amylose and amylopectin that ranged from $23.37 \%-25.30 \%$, and $27.67 \%-32.19 \%$, while the native tannia flour, $23.23 \%$, and $29.62 \%$ (Table 2). This insignificant difference indicated that the amylose or amylopectin molecules were not degraded during the parboiling process. The amylose content of the PTF was higher than of taro flour $(17.3 \%)$ and cassava flour (13.1\%), but lower compared to that of yam flour $(33.1 \%)$, which was reported by Aprianita et al. (2014). On the other hand, the amylopectin content of the PTF was lower than of yam flour $(37.0 \%)$, taro flour $(48.1 \%)$, and cassava flour (64.4\%) as suggested in Aprianita et al. (2014). The amylose and amylopectin composition of flour affects the functional properties of the flour. According to Chan et al. (2009), the amylose and amylopectin characteristics of flour have an effect on its WSI and SP. Amylose in flour plays a role in improving dough elasticity, increased food product firmness, and decrease water absorption (Hung and Morita, 2005).

Table-2: The effect of parboiling temperature and time on the moisture, amylose, and amylopectin of pregelatinized tannia flour.

\begin{tabular}{|c|c|c|c|c|c|}
\hline \multirow{2}{*}{$\begin{array}{c}\text { Parboiling } \\
\text { time } \\
\text { (minutes) }\end{array}$} & \multicolumn{3}{|c|}{$\begin{array}{c}\text { Parboiling temperature } \\
\left({ }^{\circ} \mathbf{C}\right)\end{array}$} & \multirow[t]{2}{*}{ Mean } & \multirow{2}{*}{$\begin{array}{c}\text { Native } \\
\text { tannia flour }\end{array}$} \\
\hline & 75 & 85 & 95 & & \\
\hline \multicolumn{6}{|c|}{ Moisture $(\%)^{(-)}$} \\
\hline 10 & 7.29 & 6.85 & 7.00 & $7.05^{\mathrm{A}}$ & \multirow{3}{*}{5.96} \\
\hline 15 & 6.35 & 7.08 & 6.91 & $6.78^{\mathrm{A}}$ & \\
\hline 20 & 8.19 & 7.71 & 6.63 & $7.51^{\mathrm{A}}$ & \\
\hline Mean & $7.28^{\mathrm{A}}$ & $7.21^{\mathrm{A}}$ & $6.85^{\mathrm{A}}$ & & \\
\hline \multicolumn{6}{|c|}{ Amylose $(\%)^{(-)}$} \\
\hline 10 & 23.37 & 25.20 & 24.68 & $24.42^{\mathrm{A}}$ & \multirow{3}{*}{23.23} \\
\hline 15 & 24.85 & 26.02 & 24.30 & $25.06^{\mathrm{A}}$ & \\
\hline 20 & 25.30 & 24.84 & 25.10 & $25.08^{\mathrm{A}}$ & \\
\hline Mean & $24.51^{\mathrm{A}}$ & $25.35^{\mathrm{A}}$ & $24.69^{\mathrm{A}}$ & & \\
\hline \multicolumn{6}{|c|}{ Amylopectin $(\%)^{(-)}$} \\
\hline 10 & 30.01 & 33.64 & 29.53 & $31.06^{\mathrm{A}}$ & \multirow{3}{*}{29.62} \\
\hline 15 & 27.67 & 32.54 & 32.19 & $30.80^{\mathrm{A}}$ & \\
\hline 20 & 31.99 & 28.35 & 32.15 & $30.83^{\mathrm{A}}$ & \\
\hline Mean & $29.89^{\mathrm{A}}$ & $31.51^{\mathrm{A}}$ & $31.29^{\mathrm{A}}$ & & \\
\hline
\end{tabular}

${ }^{\mathrm{A}}$ Values in row or column followed by the same letter are not significantly different $(p>0.05)$.

Interaction between parboiling temperature and time is not significant.

\section{Pasting profile}

The interaction between parboiling temperature and time was not significant $(p>0.05)$ on the pasting time, pasting temperature, and final viscosity of the PTF paste. The increase in the parboiling temperature significantly decreased the pasting time and pasting temperature of PTF; however, it did not significantly affect the final viscosity of PTF paste (Table 3). PTF with the lowest pasting time (11.06 minutes) and pasting temperature $\left(68.41^{\circ} \mathrm{C}\right)$ was produced at a parboiling temperature of $95^{\circ} \mathrm{C}$. These figures were much lower than those of native tannia flour (15.00 minutes and $81.77^{\circ} \mathrm{C}$ ). This result revealed that the functional properties of PTF were better than the native tannia flour because the energy needed for further processing was to become lower. The pasting time of PTF reported in the present study was lower than that of yam flour (22 minutes), taro flour (22 minutes) as reported in Oladeji et al. (2013). The pasting temperature of $\mathrm{PTF}$ was also lesser than that of cassava flour $\left(71.25^{\circ} \mathrm{C}-75.95^{\circ} \mathrm{C}\right.$ ) (Aldana and Quintero, 2013), and plantain flour $\left(81^{\circ} \mathrm{C}\right)$ (Oladeji et al., 2013). The results of this study indicated that the final viscosity of PTF was lower than that of native 
tannia flour (Table 3). Similar findings were also observed by Majzoobi et al. (2011) for wheat flour where the final viscosity of pregelatinized wheat flour $(3,406 \mathrm{cP})$ was lower than that of native wheat flour $(4,810 \mathrm{cP})$.

Table-3: The effect of parboiling temperature and time on the pasting temperature, pasting time, and final viscosity of pregelatinized tannia flour.

\begin{tabular}{|c|c|c|c|c|c|}
\hline \multirow{2}{*}{$\begin{array}{c}\text { Parboiling } \\
\text { time } \\
(\text { minutes })\end{array}$} & $\mathbf{7 5}$ & $\mathbf{8 5}$ & $\mathbf{9 5}$ & \multirow{2}{*}{ Mean } & $\begin{array}{c}\text { Native } \\
\text { tannia } \\
\text { flour }\end{array}$ \\
\cline { 2 - 5 } & \multicolumn{7}{|c|}{ Pasting temperature $\left({ }^{\circ} \mathrm{C}\right)^{(-)}$} \\
\hline 10 & 87.03 & 90.07 & 68.27 & $81.79^{\mathrm{A}}$ & 81.77 \\
\hline 15 & 87.50 & 89.40 & 69.37 & $82.09^{\mathrm{A}}$ & \\
\hline 20 & 86.97 & 80.93 & 67.60 & $78.50^{\mathrm{A}}$ & \\
\hline Mean & $87.17^{\mathrm{A}}$ & $86.80^{\mathrm{A}}$ & $68.41^{\mathrm{B}}$ & \\
\hline \multicolumn{7}{|c|}{ Pasting time (minutes) } \\
\hline 10 & 16.00 & 18.00 & 11.00 & $15.00^{\mathrm{A}}$ & 15.00 \\
\hline 15 & 16.33 & 17.00 & 11.33 & $14.89^{\mathrm{A}}$ & \\
\hline 20 & 16.33 & 14.67 & 10.83 & $13.94^{\mathrm{A}}$ & \\
\hline Mean & $16.22^{\mathrm{A}}$ & $16.56^{\mathrm{A}}$ & $11.05^{\mathrm{B}}$ & \\
\hline \multicolumn{7}{|c|}{ Final viscosity $(\mathrm{cP})^{(-)}$} \\
\hline 10 & 2120.00 & 895.00 & 1773.33 & $1596.11^{\mathrm{A}}$ & 3111.67 \\
\hline 15 & 2333.33 & 1620.00 & 2908.33 & $2287.22^{\mathrm{A}}$ & \\
\hline 20 & 1650.00 & 1646.67 & 3431.15 & $2242.61^{\mathrm{A}}$ & \\
\hline Mean & $2034.44^{\mathrm{A}}$ & $1387.22^{\mathrm{A}}$ & $2704.27^{\mathrm{A}}$ \\
\hline
\end{tabular}

${ }^{\mathrm{A}-\mathrm{B}}$ Values in row or column followed by the same letter are not significantly different $(p>0.05)$. ${ }^{(-)}$ Interaction between parboiling temperature and time is not significant.

As shown in Figure 1, the pasting profile of PTF differed significantly from that of native tannia flour. The native tannia flour paste showed a sharp increase in viscosity at the heating time of 13-17 minutes, with viscosity reaching $1,990.00 \mathrm{cP}$ at $93.80^{\circ} \mathrm{C}$, and then this viscosity was stable and slightly decreased until the heating time of 33 minutes. However, it began to rise again as the temperature of the paste was lowered until it reached the final viscosity of $311,167 \mathrm{cP}$ at $50^{\circ} \mathrm{C}$. Based on starch classification suggested by Schoch and Maywald (1968), the pasting profile of native tannia flour can be categorized into type B. Meanwhile, pasting profile of PTF was relatively low and without viscosity peak; therefore, the PTF pasting profile could be categorized as type $\mathrm{C}$, based on the classification according to Schoch and Maywald (1968). Type C flour has better stability against mechanical fragmentation, and its viscosity is more constant than type A and B when cooked, so it is more beneficial in terms of food processing.
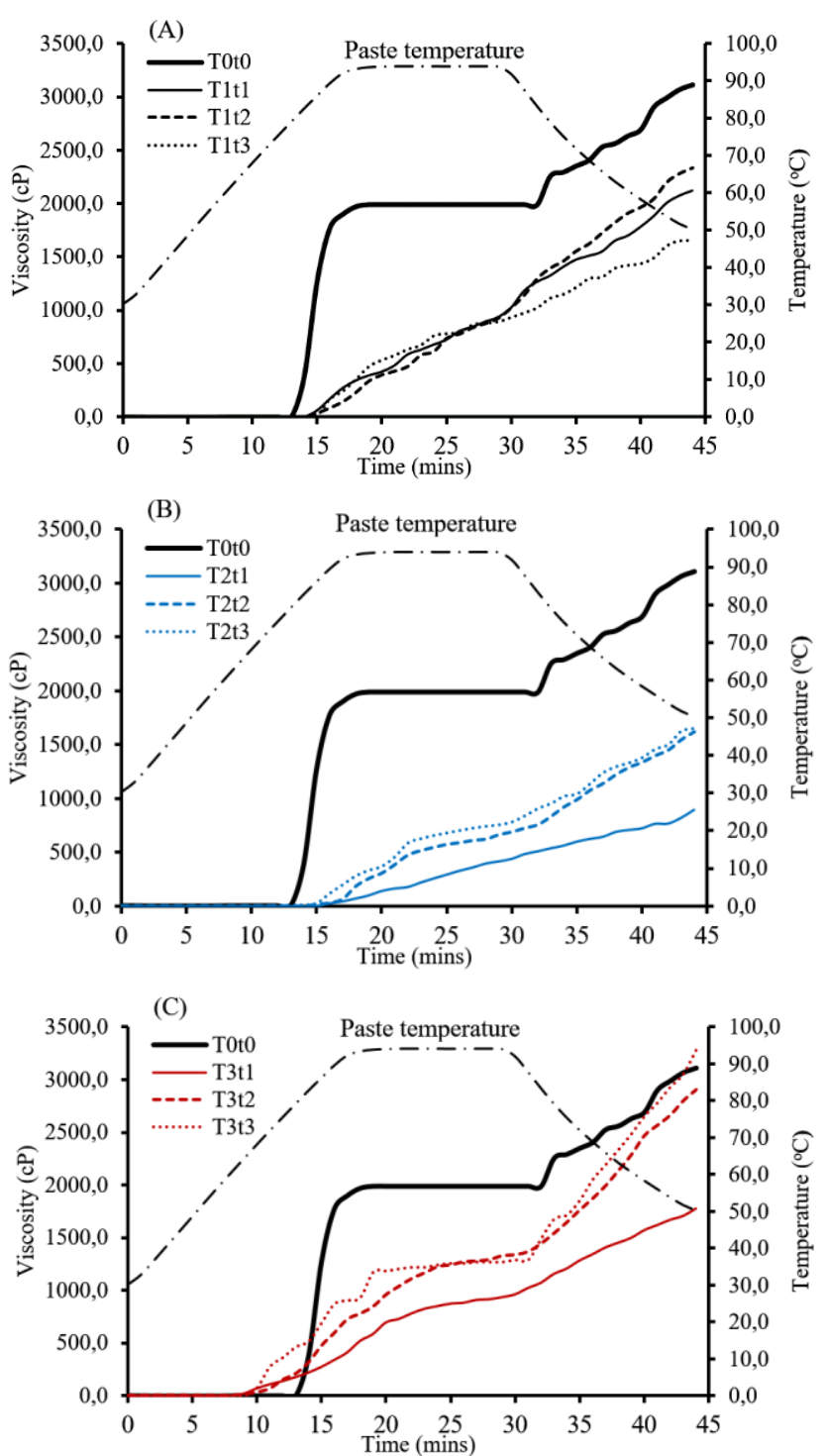

Figure-1: The viscosity profile of pregelatinized tannia flour (PTF) paste produced from the parboiling process at $75^{\circ} \mathrm{C}(\mathrm{A}), 85^{\circ} \mathrm{C}(\mathrm{B})$, and $95^{\circ} \mathrm{C}$ (C). T0t0 = native tannia flour; $T 1, T 2, T 3=$ parboiling temperature $\left(75^{\circ} \mathrm{C}, 85^{\circ} \mathrm{C}\right.$, and $\left.95^{\circ} \mathrm{C}\right)$; $t$ $1,2,3=$ parboiling temperature $(10,15$, and 20 minutes).

\section{Flour microstructure}

The microstructure of the flour samples was observed using an SEM. Figure 2 shows the differences between the native tannia flour and the PTF microstructure. This study indicated the starch granules of the native tannia flour existed in some forms: spherical, ellipsoidal, and truncated ellipsoidal. The morphology of native tannia flour starch granules had similarities to cocoyam starch granules as reported in Mweta et al. 
(2008). In this study, the size of the native tannia starch granules was observed between 10 and $20 \mu \mathrm{m}$. This result is in close conformity with the findings of Odeku (2013) which stated that native tannia starch granules could range from 2 to $50 \mu \mathrm{m}$. On the other hand, PTF did not show starch granules structure. Unlike the native tannia granules, the size of the PTF granules was much bigger (between 30 and $40 \mu \mathrm{m}$ ) (Fig. 2B). It was assumed that this structure was formed from the cellulose molecules, which seeped from the broken starch granule when the gelatinization process was accrued. When the retrogradation process took place, the cellulose molecules realigned together to form a matrix while the remaining broken granules were trapped in it. The change in the microstructure was also confirmed by Simsek and El (2012) for pregelatinized taro starch.
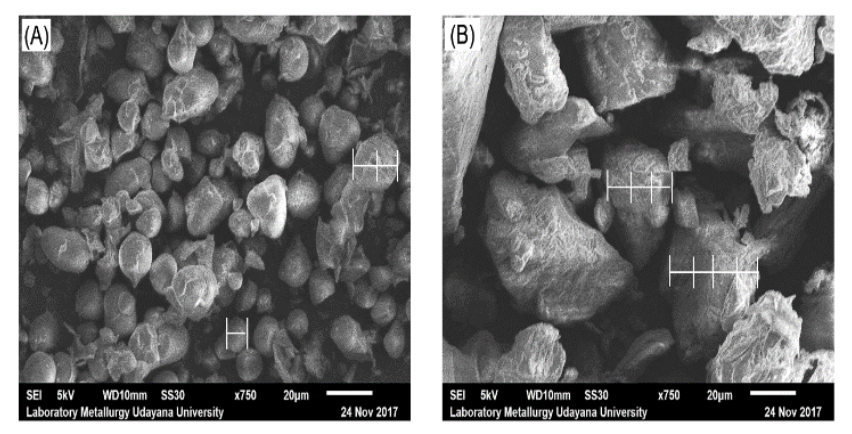

Figure-2: SEM micrograph of native tannia flour (A) and pregelatinized tannia flour (PTF) (B) at $750 \times$ magnification.

\section{Conclusion}

Parboiling temperature and time affected the functional and pasting properties of PTF, but they did not affect the chemical properties. WSI and SP were significantly affected by parboiling temperature and time, whereas WAC, pasting temperature, and pasting time were only affected by parboiling temperature. To obtain the fine PTF, parboiling would be arranged at $95^{\circ} \mathrm{C}$ for 10 minutes. This report had proven that parboiling treatment could change the microstructure and repair the physicochemical properties of tannia flour. It also successfully change the pasting profile of tannia flour from type B into type C. PTF can be used in the manufacturing of flour-based products such as simulated chips, noodles, biscuits, and cakes as a partial replacement for wheat flour.

\section{Acknowledgment}

The current research was sponsored by DIPA PNBP Udayana University based on the Letter of Agreement for Research Project (Surat Perjanjian Penugasan Pelaksanaan Penelitian) No. 67348/UN14.4.A/LT/2017.

Disclaimer: None.

Conflict of Interest: None.

Source of Funding: This study was sponsored by DIPA PNBP, Udayana University, Bali, Indonesia.

\section{References}

AAC (American Association of Cereal Chemists), 1995. Determination of pasting of rice with the rapid visco analyzer. Approved method of analysis. 9th edition, American Association of Cereal Chemists, St. Paul, MN, USA.

Adepeju AB, Gbadamosi OS, Adeniran AH and Omobuwajo TO, 2011. Functional and pasting characteristics of breadfruit (Artocarpus altilis). Afr. J. Food Sci. 5(9): 529-535.

Aldana AS and Quintero AF, 2013. Physicochemical characterization of two cassava (Manihot esculenta Crantz) starches and flours. Scientia. Agroalimentaria. 1: 19-25.

Aprianita A, Vasiljevic T, Bannikova A and Kasapis S, 2014. Physicochemical properties of flours and starches derived from traditional Indonesian tubers and roots. J. Food Sci. Technol. 51(12): 3669-3679.

Borah P and Sit N, 2015. Optimization of drying conditions of Xanthosoma sagittifolium (Tannia) tubers in tray dryer using response surface methodology. J. Food Process Preserv. 39(2): 190-198.

Chan HT, Bhat R and Karim AA, 2009. Physicochemical and functional properties of ozone-oxidized starch. J. Agric. Food Chem. 57: 5965-5970.

Egan H, Kirk R and Sawyer RP, 1981. Chemical analysis of foods. Churchill Livingstone, New York, NY, USA.

Hidayat B, Kalsum N and Surfiana S, 2009. Characterization of modified cassava flour processed through partial pregelatinization method. J. Teknol. Industri. Hasil Pertanian. 14(2): 148-159. 
Hoyos-Leyva JD, Bello-Perez LA, Yee-Madeira H, Rodriguez-Garcia ME and Aguirre-Cruz A, 2017. Characterization of the flour and starch of aroid cultivars grown in Mexico. Starch-Starke. 69: 1600370.

Hung PV and Morita N, 2005. Physicochemical properties and enzymatic digestibility of starch from edible canna (Canna edulis) grown in Vietnam. Carbohyd. Polym. 61: 314-321.

Juliano BOA, 1971. Simplified assay for milled-rice amylose. Cereal Sci. Today. 16(10): 334-340.

Kearsley MW and Dziedzic SZ, 1995. The technology of starch production. In: Dziedzic SZ, Kearsley MW (eds.). Handbook of starch hydrolysis product and their derivatives, SpringerScience+Business Media, B.V. pp. 1-25.

Khomsatin S, Sugiyono and Haryanto B, 2012. Study of the effects of steam pressure treatment on the physicochemical properties of corn flour. J. Teknol. Industri. Pangan. 23(1): 86-93.

Kumoro AC, Retnowati DS, Budiyati CS, Manurung $\mathrm{T}$ and Siswanto, 2012. Water solubility, swelling and gelatinization properties of raw and ginger oil modified gadung (Dioscorea hispida Dennst) flour. Res. J. Appl. Sci. Eng. Technol. 4(17): 2854-2860.

Kusumayanti H, Handayani NA and Santosa H, 2015. Swelling power and water solubility of cassava and sweet potatoes flour. Procedia Environ. Sci. 23: $164-167$.

Lai HM, 2001. Effects of hydrothermal treatment on the physicochemical properties of pregelatinized rice flour. Food Chem. 72: 455-463.

Majzoobi M, Radi M, Farahnaky A, Jamalian J, Tongdang T and Mesbahi Gh., 2011. Physicochemical properties of pre-gelatinized wheat starch produced by a twin drum drier $\mathrm{J}$. Agric. Sci. Technol. 13: 193-202.

Marta $H$ and Tensiska, 2017. Functional and amylographic properties of physically-modified sweet potato starch. In 2nd International Conference on Sustainable Agriculture and Food Security: a Comprehensive Approach. KnE Life Sci. 2017: 689-700.

Maulani RR and Hidayat A, 2016. Characterization of the functional properties of hydroxypropylated and cross-linked arrowroot starch in various acidic pH mediums. Int. J. Technol. 7(1): 176184.

Moorthy SN, Sajeev MS and Anish RJ, 2018. Functionality of tuber starches. In: Sjöö M,
Nilsson L (eds.). Starch in food: structure, function and applications, Woodhead Publishing, Duxford, UK, pp. 421-508.

Mweta DE, Labuschagne MT, Koen E, Benesi IRM and Saka JDK, 2008. Some properties of starches from cocoyam (Colocasia esculenta) and cassava (Manihot esculenta Crantz) grown in Malawi. Afr. J. Food Sci. 2: 102-111.

Nathania I, Sugih AK and Muljana H, 2017. Preliminary study on the synthesis of phosphorylated mung bean starch: the effect of $\mathrm{pH}$ on the physicochemical and functional properties. Indones. J. Chem. 17(3): 401-406.

Obiegbuna JE, Ishiwu CN Akubor PI and Igwe EC, 2014. Effect of processing and storage relative humidity on selected functional properties of cocoyam (Colocasia esculenta) Corm Flour. Food Sci. Qual. Manage. 28: 20-28.

Odeku OA, 2013. Potentials of tropical starches as pharmaceutical excipients. Rev. Starch-Starke. 65: 89-106.

Okporie EO, Chukwu SC, Onyishi GC, Ekwu LG and Oko GO, 2014. Increase in protein, oil, amylose and amylopectin contents of two populations of maize (Zea mays L.) after two cycles of reciprocal recurrent selection. J. Agric. Vet. Sci. 6(6): 17-22.

Oladeji BS, Akanbi CT and Gbadamosi SO, 2013. Comparative studies of physico-chemical properties of yam (Discorea rotundata), cocoyam (Collocasia taro), breadfruit (Artocapus artilis) and plantain (Musa parasidiaca) instant flours. Afr. J. Food Sci. 7(8): 210-215.

Onuegbu NC, Ihediohanma NC, Odunze OF and Ojukwu M, 2013. Efficiency of wheat: maize composite flour as affected by baking method in bread and cake production. Sky J. Food Sci. 2(8): 5-13.

Osundahusi O, Fagbemi T, Kesselman E and Shimoni E, 2003. Comparison of the physicochemical properties and pasting characteristics of flour and starch from red and white sweet potato cultivars. J. Agric. Food Chem. 51: 2232-2236.

Padmaja G, Balagopalan C, Moorthy SN and Potty VP, 2002. Yuca rava and yuca porridge: the functional properties and quality of two novel cassava products. In: Dufour D, O'Brien GM, R. Best R (eds.). Cassava flour and starch: progress in research and development, CIAT Publication, Cali, CO. pp. 323-330.

Palupi HT, Zainul A and Nugroho M, 2011. Effect of pre-gelatinization on the characteristics of cassava 
flour. J. Teknol. Pangan. 1(1):1-14.

Pérez EE, Gutiérrez ME, De Delahaye EP, Tovar J and Lares M, 2007. Production and characterization of Xanthosoma sagittifolium and Colocasia esculenta flours. J. Food Sci. 72(6): 5367-5372.

Sarma A, Burhagohain R, Barman RP, Dey SK, Phukan R, Sarmah P and Mehdi P, 2016. Variability in nutritional content of some underutilized edible aroids found in hilly terrain of Assam State of India. World J. Pharm. Pharmaceut. Sci. 5(2): 1398-1410.

Schoch TJ and Maywald EC, 1968. Preparation and properties of various legume starches. Cereal Chem. 45: 564-573.

Simsek S and El SN, 2012. Production of resistant starch from taro (Colocasia esculenta L Schott) corm and determination of its effects on health by in vitro methods. Carbohydr. Polym. 90: 12041209.

Steel RGD, Torrie JH and Dickey DA, 1997. Principles and procedures of statistics: a biometrical approach. McGraw-Hill, New York, NY, USA.

\section{Contribution of Authors}

Putra INK: Analyzed data and manuscript write up

Suparthana IP: Analyzed the chemical and physical characteristics of PTF

Ina NPT: Prepared the research material and helped in sampling and data collection 